\title{
Brachial Plexopathy: Complication of Subclavian Vein Catheterization
}

\author{
${ }^{1}$ Pankaj Beniwal, ${ }^{2}$ Vinay Malhotra, ${ }^{3}$ Mohit Mathur
}

\begin{abstract}
Central venous catheters (CVCs) are often used in critical care setting for resuscitation and monitoring and as a temporary access for hemodialysis. The increased risk of complications associated with CVCs chronic kidney disease (CKD) patients is not recognized widely. Neurological complications are extremely rare with only few cases reported. Brachial plexus injury may occur by direct needle injury or by compressive effects of a hematoma. Prompt evacuation of hematoma is warranted to prevent permanent neurological sequelae. We describe a case of brachial plexopathy after subclavian vein cannulation attempt with full recovery on conservative treatment. Prevention of such complications is the best way to reduce morbidity in CKD patients. For this timely creation of an arteriovenous fistula in CKD patients, ultrasound-guided insertion of CVCs, use of internal jugular vein as the preferred route, and close watch on coagulation defects due to uremic state is recommended.
\end{abstract}

Keywords: Central venous access, Chronic kidney disease, Platelet dysfunction, Hematoma, Brachial plexus injury.

Key messages: Chronic kidney disease (CKD) patients should have a permanent vascular access (arteriovenous fistula) well in advance of anticipated time of initiation of dialysis.

How to cite this article: Beniwal P, Malhotra V, Mathur M. Brachial Plexopathy: Complication of Subclavian Vein Catheterization. Panam J Trauma Crit Care Emerg Surg 2014;3(2):76-78.

\section{Source of support: Nil}

\section{Conflict of interest: None}

\section{RESUMEN}

Los catéteres venosos centrales (CVC) se utilizan a menudo en la unidad de cuidados intensivos para reanimación y monitoreo y como una vía de acceso temporal para hemodiálisis. El aumento del riesgo de complicaciones por CVC asociados a la insuficiencia renal crónica no es ampliamente reconocido. Las complicaciones neurológicas son extremadamente raras con sólo un mínimo de casos reportados. Una lesión del plexo braquial puede producirse por lesión directa atreves de la aguja o por efectos compresivos de un hematoma. La evacuación

\footnotetext{
${ }^{1}$ Assistant Professor, ${ }^{2}$ Professor, ${ }^{3}$ Senior Resident

${ }^{1-3}$ Department of Nephrology, SMS Medical College and Hospital, Jaipur, Rajasthan, India
}

Corresponding Author: Pankaj Beniwal, Assistant Professor Department of Nephrology, SMS Medical College and Hospital Jaipur 302004, Rajasthan, India, Phone: 01412518241, e-mail: pankajbeniwal@rediffmail.com rápida de un hematoma garantiza prevenir las secuelas neurológicas permanentes. A continuación describimos un caso de plexopatía braquial después de canalización de la vena subclavia, con una recuperación completa mediante tratamiento conservador. La prevención de tales complicaciones es la mejor manera de reducir la morbilidad en los pacientes con insuficiencia renal crónica. Para esto es necesario y se sugiere la creación oportuna de una fístula arteriovenosa en aquellos pacientes, inserción de un CVC guiada por ultrasonido, uso de la vena yugular interna como la ruta preferida, y observación cercana de defectos de la coagulación debido a estado urémico.

Palabras claves: Acceso venoso central, Enfermedad renal crónica, Disfunción plaquetaria, Hematoma, Lesión del plexo braquial.

\section{INTRODUCTION}

Percutaneous central venous cannulation is a useful and commonly-performed procedure across medical and surgical specialities. Central vein catheterization for hemodialysis access is usually undertaken while the patient waits for a more permanent solution, such as recovery of renal function, construction of an arteriovenous (AV) fistula, or kidney transplant. The internal jugular (IJV), subclavian, and femoral veins approaches are commonly used for central venous catheterization. Neurologic complications associated with central venous cannulation are extremely rare with only a few cases reported. We present a case of brachial plexus injury caused by a compressive hematoma who recovered completely except for mild paresthesias in his forearm.

\section{CASE HISTORY}

A 52-year-old man with chronic kidney disease (CKD) stage 5 was admitted for subclavian vein (SCV) catheterization as a hemodialysis access procedure. He was a diabetic of 10 years duration and had hypertension with CKD for the last 2 years. A left radiocephalic and brachiocephalic fistula for hemodialysis was attempted earlier that had failed. A temporary right internal jugular catheter was placed 5 months back for hemodialysis, which was removed after 3 sessions of hemodialysis.

An infraclavicular SCV catheterization was attempted on the right side. During multiple attempts to place the doublelumen SCV catheter, the patient complained of a sudden electrical sensation over the right lateral shoulder and down the medial aspect of his right arm. Subclavian catheterization 

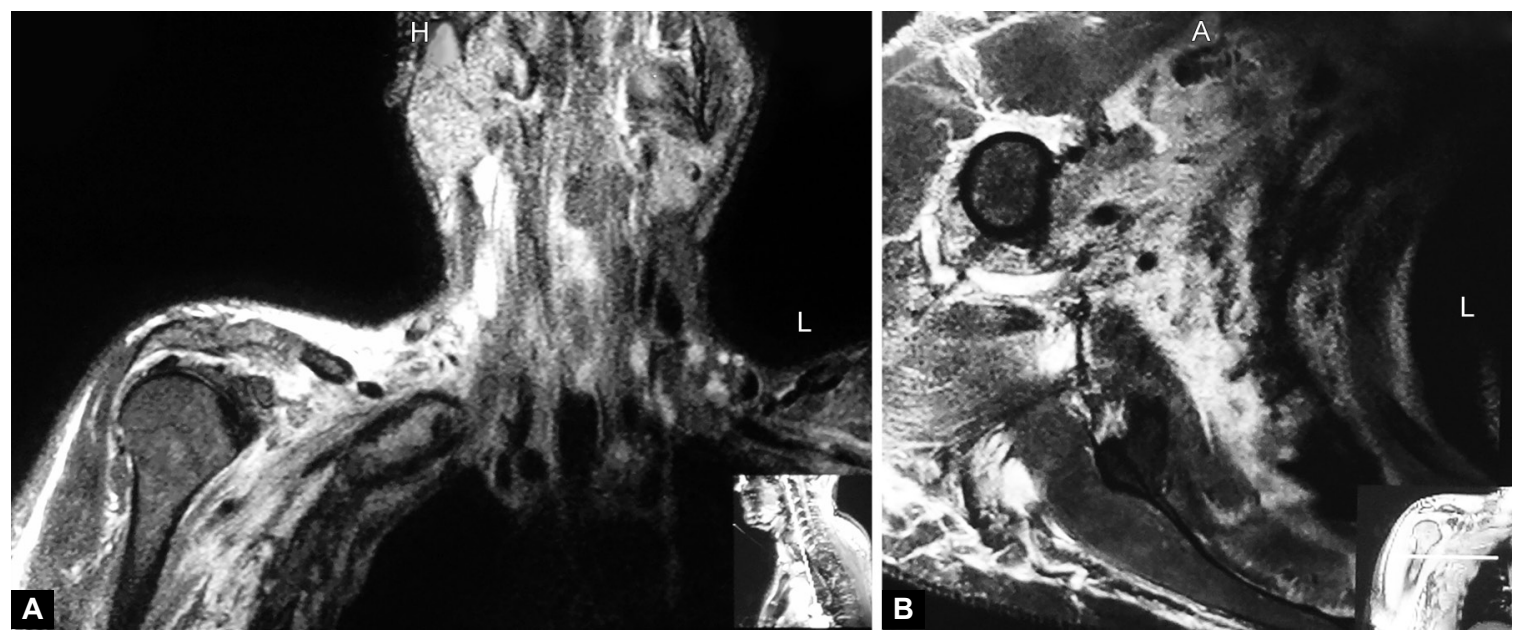

Figs 1A and B: (A) Sagittal magnetic resonance imaging [short tau inversion recovery (STIR)] showing hematoma compressing over the right brachial plexus, (B) Axial magnetic resonance image (STIR) showing a hematoma located near the subclavian vein

procedure was abandoned and another catheter was subsequently placed via the right femoral vein. A session of heparin-free hemodialysis was given and patient was discharged after observing for 24 hours. Next day at home, he experienced pain, numbness, and paresthesias over right shoulder region, arm and forearm. When he presented to the hospital, the patient noticed swelling over right shoulder region and back with difficulty in lifting his right hand above the shoulder and also difficulty in performing fine manipulations with his right hand. The vital signs revealed tachycardia (pulse rate $110 / \mathrm{min}$ ), normal respiratory rate, and blood pressure of 110/60 $\mathrm{mm} \mathrm{Hg}$. Peripheral pulses were symmetrically palpable in both upper limbs.

Neurological examination of the patient revealed muscle weakness of right arm, right forearm, and the 4th and 5th fingers. A magnetic resonance imaging scan showed a hematoma near the right $\mathrm{SCV}$ and compression of the brachial plexus (Figs 1A and B).

An electromyography was obtained that was suggestive of brachial plexopathy. His routine investigations revealed a fall in hemoglobin from 10.5 to $7 \mathrm{gm} / \mathrm{dl}$ for which packed cell transfusion was done. His coagulation parameters (bleeding time, clotting time, prothrombin time and activated partial thromboplastin time) were sent, which revealed a prolonged bleeding time. His medication had included antiplatelet agent acetylsalicylic acid.

Patient was managed with packed cell transfusions, fresh frozen plasma transfusion, and other supportive measures. Cardiothoracic consultation was obtained, but the patient was advised conservative management. The patient was seen by a neurologist who advised intensive physiotherapy. Over 6 weeks from the injury, patient noticed gradual improvement in movements of right upper limb. Patient underwent a live-related renal transplant 2 months after injury and continues to do well.

\section{DISCUSSION}

The clinical insertion of a CVC in the SCV was first described in 1952 by Aubaniac. ${ }^{1}$ SCV catheterization is associated with an overall complication rate of $29.3 \%$ and major complications in $2.6 \%{ }^{2}$ The spectrum of complications includes subclavian arterial puncture, pneumothorax, hemothorax, mediastinal hematoma, and, rarely, neurological injury. ${ }^{3}$ Arterial puncture during SCV catheterization attempts occurs in up to $3.7 \%$ of the patients. ${ }^{4}$ Brachial plexopathies can follow $\mathrm{IJV}^{5}$ or $\mathrm{SCV}^{6}$ catheterization and are transient if needle injury or local anesthetic is the cause of the symptoms. Multiple punctures or hematoma can lead to progressively worsening symptoms, resulting sometimes in permanent damage. ${ }^{7}$ Typically, IJV insertions are associated with injury to the upper trunk and SCV access with the lower trunk of the brachial plexus.

Prompt evacuation of the hematoma causing compression over brachial plexus is indicated in most cases. Early surgical intervention of compressive hematoma results in improvement of neurological symptoms in almost all cases, but delayed intervention may result in permanent neurological damage. ${ }^{8}$ Our patient was treated conservatively and except for mild residual paresthesia in his forearm, neurological deficit gradually improved.

Our case also highlights the importance of timely creation of vascular access (an AV fistula) in CKD patients. The National Kidney Foundation Kidney Disease Outcomes Quality Initiative guidelines suggest that the patient be referred for the creation of an AV fistula when the patient's creatinine clearance is at $25 \mathrm{ml} / \mathrm{min}$ or less, their serum creatinine is $4 \mathrm{mg} / \mathrm{dl}$ or less, or within 1 year of anticipated need. ${ }^{9}$ Indeed, a well-functioning fistula in this patient would have averted this complication. Uremic bleeding caused by acquired platelet dysfunction is a major cause of morbidity and mortality in end stage renal disease (ESRD) patients. The 
bleeding problems are characterized by abnormal prolongation of bleeding time and hemorrhagic symptoms. ESRD patients undergoing central vein cannulation should have their coagulation parameters checked. Aspirin discontinuation is not generally required prior to invasive procedures. Considering the uremic platelet dysfunction in patients with $\mathrm{CKD}$, it is prudent to stop the drug for 5 to 7 days prior to an invasive procedure.

The best way to care for arterial perforations during $\mathrm{CVC}$ insertion is to avoid them, and the first preventive step to be taken is to recognize that the needle entering the vessel is actually in a vein. Real-time, ultrasound-guided central venous cannulation results in a lower technical failure rate, faster access, and a reduction in mechanical complications. Ultrasound-guided central venous cannulation was considered mainly for IJV previously but has been found to be superior to landmark method for subclavian route as well. ${ }^{10}$ Pain and paresthesia in a patient undergoing venipuncture cannot be considered as normal consequences of venous catheterization but must always suggest the possibility of neurologic complications. Subclavian venous access is associated with an increased risk of central venous stenosis and mechanical complications as compared to internal jugular. Internal jugular cannulation should be the method of choice for temporary hemodialysis access.

\section{REFERENCES}

1. Aubaniac R. Subclavian intravenous injection; advantages and technic. Presse Med 1952 Oct;60(68):1456.

2. Yerdel MA, Karayalcin K, Aras N, Bozatli L, Yildirim E, Anadol E. Mechanical complications of subclavian venous catheterization. A prospective study. Int Surg 1991 Jan-Mar;76(1):18-22.

3. Defalque RJ, Fletcher MV. Neurologic complications of central venous cannulation. JPEN J Parenter Enteral Nutr 1988 Jul-Aug; 12(4):406-409.

4. Mansfield PF, Hohn DC, Fornage BD, Gregurich MA, Ota DM. Complications and failures of subclavian-vein catheterization. N Engl J Med 1994 Dec 29;331(26):1735-1738.

5. Sylvestre DL, Sandson TA, Nachmanoff DB. Transient brachial plexopathy as a complication of internal jugular vein cannulation. Neurology 1991 May;41(5):760.

6. Ramdial P, Singh B, Moodley J, Haffejee AA. Brachial plexopathy after subclavian vein catheterization. J Trauma 2003 Apr; 54(4):786-787.

7. McCready RA, Procter CD, Hyde GL. Subclavian-axillary vascular trauma. J Vasc Surg 1986 Jan;3(1):24-31.

8. Fuller GN, Dick JP, Colquhoun IR. Brachial plexus compression by hematoma following jugular puncture. Neurology 1994 Apr; 44(4):775-776.

9. NKF-K/DOQI Clinical Practice Guidelines for Vascular Access: Guideline 8: timing of access placement. Am J Kidney Dis 2001; 37 (Suppl 1):S147-S148.

10. Fragou M, Gravvanis A, Dimitriou V, Papalois A, Kouraklis G, Karabinis A, Saranteas T, Poularas J, Papanikolaou J, Davlouros $\mathrm{P}$, et al. Real-time ultrasound-guided subclavian vein cannulation versus the landmark method in critical care patients: a prospective randomized study. Crit Care Med 2011 Jul;39(7):1607-1612. 